\title{
Survey of Soil Seed Bank in Two Secondary Forests in Nnamdi Azikiwe University Awka, Nigeria
}

\author{
K. U. Ekwealor, C. F. Iroka*, K. C. Okeakpu, H. N. Eze, W. C. Anyanele \\ Department of Botany, Nnamdi Azikiwe University Awka, Nigeria
}

Received March 12, 2020; Revised April 29, 2020; Accepted May 13, 2020

Copyright $\odot 2020$ by authors, all rights reserved. Authors agree that this article remains permanently open access under the terms of the Creative Commons Attribution License 4.0 International License

\begin{abstract}
The survey of soil seed bank in two secondary forests in Nnamdi Azikiwe University Awka was conducted through random collection of soil samples on the study areas at different depths, taking records of the time of germination and number of sprouts on the soil and carrying out taxonomic identification of the species of plants that sprout on the soil samples. The result revealed that for the botanical garden study site, 13 species were identified at soil depth of $0-5 \mathrm{~cm}, 9$ species were identified at soil depth of $6-10 \mathrm{~cm}$ while 2 species were identified at soil depth of $11-15 \mathrm{~cm}$. For the law faculty forest site, 12 species were identified at soil depth of $0-5 \mathrm{~cm}, 9$ species were identified at $6-10 \mathrm{~cm}$ while 4 species were identified at soil depth of $11-15 \mathrm{~cm}$. Specifically, 18 species were identified in botanical garden forest while 15 species were identified in law faculty forest sites with seeds of species like Ageratum conyzoides, Sorghum halepense, Phyllantus niruri found at both sites. About half the species identified were found at soil depth of $0-5 \mathrm{~cm}$ while slightly above one-third of species identified were found at soil depth of $6-10 \mathrm{~cm}$. The Pearson Momentum Correlation of abundance and diversity measures of the study sites revealed that species diversity was significantly and positively correlated with soil depth while the number of species was significantly and negatively correlated with soil dept. Soil seed bank plays an important role in the vegetation restoration process. This study suggested that the soil seed bank would be adequate to enable a functional cover of indigenous vegetation to re-establish after clearing.
\end{abstract}

Keywords Seed Bank, Forest, Abundance, Diversity, Vegetation, Germination, Distribution, Species

\section{Introduction}

The term soil seed bank has been to designate the viable seed reservoir present in a soil [1]. This reservoir corresponds to the seeds not germinated but, potentially capable of replacing the annual adult plants, which had disappeared by natural death or not and perennial plants that are susceptible to plant diseases, disturbance and animal consumption, including man [2]. Soil seed banks contribute to the diversity and dynamics of most plant for maintenance of species population or for restoration of native plant communities [3,4]. All the viable seed present in the soil or mixed to soil debris constitute the soil seed banks. The earlier studies of soil seed banks started in 1859 with Darwin, when he observed the emergency of seedlings, using soil seed banks contribute to the diversity and dynamics of most plant communities. Moreover, because seed longevity varies greatly among taxa, the composition and diversity of the seed bank can differ substantially from that of the local vegetation $[5,6]$.

In agro ecosystems, the soil seed bank is closely related to weed studies; most of the seeds in the seed bank come from the nearby parent plants, while the remaining seeds are contributed by plant communities a long distance away from the parent plant [7]. Thompson and Grime recognized two main seed bank strategies. Transient types in which no seed remain viable for more than one year and persistent seed bank allows species to survive episodes of disturbance and destruction [8].

Seed bank plays a critical role in vegetation maintenance, succession, ecosystem restoration, differential species management and conservation of genetic variability [9]. It is well known that soil seed banks, which are considered to be a potential vegetation community, can facilitate the renewal of vegetation [10]. Soil seed bank have been applied widely in vegetation restoration projects. Therefore, such projects have been widely studied. Seed bank also called Diaspore banks consists of seeds and fruits as well as of vegetative parts of plants. Seeds are able to remain viable in the soil for different periods of time depending on species but also soil conditions [11-14]. 
The study aimed to carry out a survey on the soil seed bank of two secondary forests at Nnamdi Azikiwe University, Awka through the collection of soil samples at the study areas randomly using different depths, taking records of the time of germination /sprout on the soil and taxonomical identification of the species of plants that sprout out on the soil samples. Thus, this study will also shade more light on the relevance of the restoration of plant community and the conditions under which persistent soil seed banks evolved.

\section{Materials and Methods}

\subsection{Site Description}

This practical was carried out in the department of Botany Green House, Nnamdi Azikiwe University, Awka Anambra State where "two secondary forests" was sampled at different soil levels.

The two secondary forests sampled are;

Forest I: Botanical Garden Forest

Forest II: The Forest behind Law Faculty

Each forest has three (3) different sites where soil was collected at different soil level ranging from $0-5 \mathrm{~cm}$, $6-10 \mathrm{~cm}$, and $11-15 \mathrm{~cm}$.

\subsection{Parameters Monitored Were:}

1. Date of Germination: Sample collection was done on $30^{\text {th }}$ of July, 2019. Nine days after the collection, tiny outgrowths of plants were observed. And these outgrowths were observed from soil sample of forest I and II of Site I which is $(0-5 \mathrm{~cm})$ depth at Botanical Garden Forest and Behind Law Faculty Forest respectively. Other soil levels $(6-10 \mathrm{~cm})$ and $(11-15 \mathrm{~cm})$ showed no growth as at that date. Two weeks after, other levels $0-5 \mathrm{~cm}$ and $6-10 \mathrm{~cm}$ of the soil sample I and II i.e. forest I and II showed more growth. Growth was noticed in some of the soil levels of $(11-15 \mathrm{~cm})$ of the forest on the $14^{\text {th }}$ September, 2019 i.e. a month and two weeks with less number of outgrowths.

2. Number of Outgrowths: Number of outgrowths of plants as at $14^{\text {th }}$ September, 2019. Of the two secondary forests i.e. Forest I and II are as follows.

$\begin{array}{lll}\text { Forest I } & \text { Site I }(0-5 \mathrm{~cm}) & 20 \text { plants } \\ & \text { Site II }(0-5 \mathrm{~cm}) & 30 \text { plants } \\ & \text { Site III }(0-5 \mathrm{~cm}) & 31 \text { plants } \\ \text { Forest I } & \text { Site I }(6-10 \mathrm{~cm}) & 12 \text { plants } \\ & \text { Site II }(6-10 \mathrm{~cm}) & 4 \text { plants } \\ & \text { Site III }(6-10 \mathrm{~cm}) & 9 \text { plants } \\ \text { Forest I } & \text { Site I }(11-15 \mathrm{~cm}) & \text { no outgrowth } \\ & \text { Site II }(11-15 \mathrm{~cm}) & 3 \text { plants } \\ & \text { Site III }(11-15 \mathrm{~cm}) & \text { no outgrowth } \\ \text { Forest II } & \text { Site I }(0-5 \mathrm{~cm}) & 4 \text { plants }\end{array}$

$\begin{array}{lll} & \text { Site II }(0-5 \mathrm{~cm}) & 59 \text { plants } \\ & \text { Site III }(0-5 \mathrm{~cm}) & 19 \text { plants } \\ \text { Forest II } & \text { Site I }(6-10 \mathrm{~cm}) & 2 \text { plants } \\ & \text { Site II }(6-10 \mathrm{~cm}) & 5 \text { plants } \\ & \text { Site III }(6-10 \mathrm{~cm}) & 7 \text { plants } \\ \text { Forest II } & \text { Site I }(11-15 \mathrm{~cm}) & 1 \text { plant } \\ & \text { Site II }(11-15 \mathrm{~cm}) & 1 \text { plant } \\ & \text { Site III }(11-15 \mathrm{~cm}) & 3 \text { plants }\end{array}$

\subsection{Methods of Collections of Soil Samples}

Each site of the two secondary forests was mapped out with the land area of $60 \mathrm{~cm}$ by $60 \mathrm{~cm}$ wide and $15 \mathrm{~cm}$ depth were established in a homogenous area and marked with pegs, before sampling/collecting the soil.

Each site was sampled in triplicate at different soil depth which are $(0-5 \mathrm{~cm}),(6-10 \mathrm{~cm})$ and $(11-15 \mathrm{~cm})$ respectively. The total number of species found in each site was taken down and the percentage frequency was calculated with the formula.

$$
\% \text { frequency }=\frac{\text { numberoftimeseach species occured }}{\text { Total number of species }} \times \frac{100}{1}
$$

\subsection{Identification}

After germination, taxonomic identification of different species of plants in each sampled soil was done. The plants were carefully identified using observable features and a hand book of West African weeds and Vascular plant taxonomy borrowed from Department of Botany Herbarium under the supervision of Mr Iroka Finian a taxonomist in the department; the identified species were counted and recorded.

\subsection{Seed Diversity}

The number (size) of weed seeds in the seed bank (Y) per land area $\left(\mathrm{m}^{2}\right)$ was estimated by multiplying the number of seeds in soil sample $(G)$ by the inverse ratio of the volume of soil in the auger sample to the volume of soil in $1 \mathrm{~m}^{2}$ area sampled to the depth of the auger (15 $\mathrm{cm})$.

\subsection{Computation of Species Diversity}

Shannon - Wiener index of diversity was used to determine the species diversity of the sampled plots using the formulae:

$$
\begin{aligned}
& \mathrm{H}^{1}=\mathrm{I} \sum(\text { pi X In Pi) } \\
& \mathrm{H}^{1} \max =\mathrm{In} \mathrm{s} \\
& \mathrm{E}=\text { Equitability }=\underline{\mathrm{H}^{1} / \mathrm{H}} \text { max. } \\
& \text { Where: } \\
& \mathrm{H}^{1} \text { max = Maximum equitability } \\
& \mathrm{H}^{1}=\text { Shannon Wieners index. }
\end{aligned}
$$


$\mathrm{Pi}=$ Proportion of $\mathrm{i}$ species in the community.

In $=$ natural $\log$.

$\mathrm{S}=$ total no. of species.

Pearson momentum correlation coefficient to determine relationships between measure of abundance and diversity

\section{Results}

\subsection{Seed Bank Abundance of the Study Sites}

Table 1 shows distribution of seed banks of the study sites. The table revealed that for the botanical garden study site, 13 species were identified at soil depth of $0-5 \mathrm{~cm}, 9$ species were identified at soil depth of $6-10 \mathrm{~cm}$ while 2 species were identified at soil depth of $11-15 \mathrm{~cm}$. For the law faculty forest site, 12 species were identified at soil depth of $0-5 \mathrm{~cm}, 9$ species were identified at $6-10 \mathrm{~cm}$ while 4 species were identified at soil depth of $11-15 \mathrm{~cm}$. Specifically, 18 species were identified in botanical garden while 15 species were identified in law faculty forest sites with some seeds of species like Ageratum conyzoides, Sorghum halepense, Phyllantus niruri and others found at both sites, this place the total number of species identified in both sites to be 24. About half the species identified were found at soil depth of $0-5 \mathrm{~cm}$ while slightly above one-third of species identified were found at soil depth of $6-10 \mathrm{~cm}$. less than $20 \%$ of total species identified were found at soil depth of $11-15 \mathrm{~cm}$.

Table 1. Distribution of Seed banks of the Study Sites

\begin{tabular}{|c|c|c|c|c|c|c|c|}
\hline \multirow{2}{*}{ SN } & \multirow{2}{*}{ Species name } & \multicolumn{3}{|c|}{ Site 1: Botanical Garden } & \multicolumn{3}{|c|}{ Site 2: Behind Law faculty } \\
\hline & & $0-5 \mathrm{~cm}$ & $6-9 \mathrm{~cm}$ & $10-15 \mathrm{~cm}$ & $0-5 \mathrm{~cm}$ & $6-9 \mathrm{~cm}$ & $10-15 \mathrm{~cm}$ \\
\hline 1 & Aciola bateri & $*$ & & & & & \\
\hline 2 & Adiantum $s p$ & & $*$ & & & & \\
\hline 3 & Ageratum conyzoides & $*$ & $*$ & $*$ & * & & \\
\hline 4 & Asystacia gigantica & $*$ & & & & & \\
\hline 5 & Cleome rutidosperma & & & & & * & $*$ \\
\hline 6 & Commelina diffusa & & & & * & & \\
\hline 7 & Dissotis runtoidifolia & & & & & $*$ & \\
\hline 8 & Dissotis sp & $*$ & & & & & \\
\hline 9 & Setaria parviflora & & & & * & & \\
\hline 10 & Eleusine indica & $*$ & $*$ & & * & & \\
\hline 11 & Euphorbia heterophylla & * & & & $*$ & $*$ & \\
\hline 12 & Johnson grass & $*$ & $*$ & & * & * & \\
\hline 13 & Kyllinga erecta & & & & * & $*$ & $*$ \\
\hline 14 & Laportea ovaliformis & $*$ & $*$ & & & & \\
\hline 15 & Mitracarpus scaber & $*$ & & & $*$ & $*$ & $*$ \\
\hline 16 & Oldenlanda corymbosa & $*$ & & & $*$ & & \\
\hline 17 & Oldenlandia corymbosa & & $*$ & & & & \\
\hline 18 & Phyllantis amarus & $*$ & & & & $*$ & \\
\hline 19 & Phyllantus niruri & $*$ & $*$ & * & * & $*$ & \\
\hline 20 & Poulzozia guineense & & & & * & $*$ & $*$ \\
\hline 21 & S. monostadynus & & * & & & & \\
\hline 22 & Spigelia anthelmia & $*$ & & & $*$ & & \\
\hline 23 & Unidentified plant $A$ & & $*$ & & & & \\
\hline \multirow[t]{3}{*}{24} & Unidentified plant $B$ & & $*$ & & & & \\
\hline & Total countered spp & 13 & 10 & 2 & 12 & 9 & 4 \\
\hline & $\%$ & $54 \%$ & $42 \%$ & $8 \%$ & $50 \%$ & $38 \%$ & $16 \%$ \\
\hline
\end{tabular}


Table 2. Species Abundance of Seed banks at Botanical Garden Forest at Soil Dept of 0-5cm

\begin{tabular}{|c|c|c|c|c|c|c|c|}
\hline SN & Species & $\begin{array}{c}\text { Seed density } \\
\left(\mathrm{M}^{-2}\right)\end{array}$ & $\begin{array}{c}\text { Seed Rel. } \\
\text { Density (\%) }\end{array}$ & $\begin{array}{c}\text { Seed Freq } \\
(\%)\end{array}$ & $\begin{array}{l}\text { Seed Rel. } \\
\text { Freq (\%) }\end{array}$ & $\begin{array}{l}\text { IVI } \\
(\%)\end{array}$ & Rank \\
\hline 1 & Aciola bateri & 82 & 1.24 & 33 & 5.9 & 7.09 & 7 \\
\hline 2 & Ageratum conyzoides & 1309 & 19.74 & 100 & 17.7 & 37.47 & 2 \\
\hline 3 & Asystacia gigantica & 82 & 1.24 & 33 & 5.9 & 7.09 & 7 \\
\hline 4 & Dissotis sp & 82 & 1.24 & 33 & 5.9 & 7.09 & 7 \\
\hline 5 & Eleusine indica & 2373 & 35.79 & 67 & 11.9 & 47.67 & 1 \\
\hline 6 & $\begin{array}{c}\text { Euphorbia } \\
\text { heterophylla }\end{array}$ & 82 & 1.24 & 33 & 5.9 & 7.09 & 7 \\
\hline 7 & Sorghum halenpense & 1555 & 23.45 & 33 & 5.9 & 29.31 & 3 \\
\hline 8 & Laportea ovaliformis & 164 & 2.47 & 33 & 5.9 & 8.32 & 6 \\
\hline 9 & Mitracarpus scaber & 82 & 1.24 & 33 & 5.9 & 7.09 & 7 \\
\hline 10 & $\begin{array}{c}\text { Oldenlandia } \\
\text { corymbosa }\end{array}$ & 164 & 2.47 & 67 & 11.9 & 14.35 & 4 \\
\hline 11 & Phyllanthus amarus & 82 & 1.24 & 33 & 5.9 & 7.09 & 7 \\
\hline 12 & Phyllantus niruri & 491 & 7.41 & 33 & 5.9 & 13.26 & 5 \\
\hline \multirow[t]{2}{*}{13} & Spigelia anthelmia & 82 & 1.24 & 33 & 5.9 & 7.09 & 7 \\
\hline & Total & 6630 & 100.00 & 564 & 100.0 & 200.00 & \\
\hline
\end{tabular}

Table 3. Species Abundance of Seed banks at Botanical Garden Forest at Soil Dept of 6-10cm

\begin{tabular}{|c|c|c|c|c|c|c|c|}
\hline SN & Species & $\begin{array}{c}\text { Seed } \\
\text { density } \\
\left(\mathbf{M}^{-2}\right) \\
\end{array}$ & $\begin{array}{c}\text { Seed Rel. } \\
\text { Density (\%) }\end{array}$ & Seed Freq (\%) & $\begin{array}{l}\text { Seed Rel. } \\
\text { Freq (\%) }\end{array}$ & IVI (\%) & Rank \\
\hline 1 & Adiantum $s p$ & 327 & 15.97 & 33 & 8.3 & 24.27 & 3 \\
\hline 2 & Ageratum conyzoides & 164 & 8.01 & 67 & 16.8 & 24.85 & 2 \\
\hline 3 & Eleusine indica & 818 & 39.96 & 67 & 16.8 & 56.80 & 1 \\
\hline 4 & Sorghum halenpanse & 164 & 8.01 & 33 & 8.3 & 16.30 & 4 \\
\hline 5 & Laportea ovaliformis & 164 & 8.01 & 33 & 8.3 & 16.30 & 4 \\
\hline 6 & Oldenlandia corymbosa & 82 & 4.01 & 33 & 8.3 & 12.30 & 6 \\
\hline 7 & Phyllantus niruri & 82 & 4.01 & 33 & 8.3 & 12.30 & 6 \\
\hline 8 & $\begin{array}{l}\text { Solenostemon } \\
\text { monostachyus }\end{array}$ & 82 & 4.01 & 33 & 8.3 & 12.30 & 6 \\
\hline 9 & Unidentified plant $A$ & 82 & 4.01 & 33 & 8.3 & 12.30 & 6 \\
\hline \multirow[t]{2}{*}{10} & Unidentified plant $B$ & 82 & 4.01 & 33 & 8.3 & 12.30 & 6 \\
\hline & Total & 2047 & 100 & 398 & 100 & 200 & \\
\hline
\end{tabular}

Table 4. Species Abundance of Seed banks at Botanical Garden Forest at Soil Dept of 11-15cm

\begin{tabular}{cccccccc}
\hline SN & Species & $\begin{array}{c}\text { Seed density } \\
\left(\mathbf{M}^{-2}\right)\end{array}$ & $\begin{array}{c}\text { Seed Rel. } \\
\text { Density (\%) }\end{array}$ & $\begin{array}{c}\text { Seed } \\
\text { Freq (\%) }\end{array}$ & $\begin{array}{c}\text { Seed Rel. } \\
\text { Freq (\%) }\end{array}$ & IVI (\%) & Rank \\
\hline 1 & 164 & 66.67 & 33 & 50.0 & 116.67 & 1 \\
2 & $\begin{array}{c}\text { Adiantum } s p \\
\text { Ageratum } \\
\text { conyzoides } \\
\text { Total }\end{array}$ & 82 & 33.33 & 33 & 50.0 & 83.33 & 2 \\
& 246 & 100.00 & 66 & 100.0 & 200.00 & \\
\hline
\end{tabular}

Table 2 shows the species abundance of seed banks of botanical garden sampled at soil depth of $0-5 \mathrm{~cm}$. The table revealed that Eleusine indica recorded the highest important value index of $47.67 \%$ and therefore the most abundance. Eleusine indica is followed by Ageratum conyzoides and Sorghum halenpense with important value index of $37.47 \%$ and $29.31 \%$ respectively.

Table 3 shows the species abundance of seed banks of botanical garden sampled at soil depth of $6-10 \mathrm{~cm}$. The table indicated that Eleusine indica again recorded the highest important value index of $56.80 \%$ and therefore the most abundance. Eleusine indica is followed by Ageratum conyzoides and Adiantum $s p$ with important value index of $28.85 \%$ and $24.27 \%$ respectively.

Table 4 reveals the species abundance of seed banks of botanical garden at sampled soil depth of $11-15 \mathrm{~cm}$. The table showed that out of the two species identified that the soil depth, Adiantum $s p$ recorded the higher important value index of $116.67 \%$ compared to Ageratum conyzoides with important value index of $83.33 \%$. 
Table 5. Species Abundance of Seed banks at Law Faculty Forest at Soil Dept of 0-5cm

\begin{tabular}{|c|c|c|c|c|c|c|c|}
\hline SN & Species & $\begin{array}{c}\text { Seed density } \\
\left(\mathbf{M}^{-2}\right)\end{array}$ & $\begin{array}{c}\text { Seed Rel. } \\
\text { Density (\%) }\end{array}$ & $\begin{array}{c}\text { Seed } \\
\text { Freq }(\%)\end{array}$ & $\begin{array}{l}\text { Seed Rel. } \\
\text { Freq (\%) }\end{array}$ & IVI (\%) & Rank \\
\hline 1 & Ageratum conyzoides & 1555 & 23.17 & 67 & 11.2 & 34.35 & 2 \\
\hline 2 & Commelina diffusa & 164 & 2.44 & 33 & 5.5 & 7.95 & 8 \\
\hline 3 & Sateria parviflora & 164 & 2.44 & 33 & 5.5 & 7.95 & 8 \\
\hline 4 & Eleusine indica & 164 & 2.44 & 67 & 11.2 & 13.63 & 5 \\
\hline 5 & $\begin{array}{c}\text { Euphorbia } \\
\text { heterophylla }\end{array}$ & 82 & 1.22 & 33 & 5.5 & 6.73 & 10 \\
\hline 6 & Sorghum halenpense & 164 & 2.44 & 67 & 11.2 & 13.63 & 5 \\
\hline 7 & Kyllinga erecta & 982 & 14.63 & 100 & 16.7 & 31.33 & 3 \\
\hline 8 & Mitracarpus scaber & 327 & 4.87 & 33 & 5.5 & 10.38 & 7 \\
\hline 9 & $\begin{array}{c}\text { Oldenlandia } \\
\text { corymbosa }\end{array}$ & 2373 & 35.35 & 67 & 11.2 & 46.54 & 1 \\
\hline 10 & Phyllantus riniri & 82 & 1.22 & 33 & 5.5 & 6.73 & 10 \\
\hline 11 & Poulzozia guineense & 82 & 1.22 & 33 & 5.5 & 6.73 & 10 \\
\hline \multirow[t]{2}{*}{12} & Spigelia arthemia & 573 & 8.54 & 33 & 5.5 & 14.05 & 4 \\
\hline & Total & 6712 & 100.00 & 599 & 100.0 & 200.00 & \\
\hline
\end{tabular}

Table 6. Species Abundance of Seed banks at Law Faculty Forest at Soil Dept of 6-10cm

\begin{tabular}{|c|c|c|c|c|c|c|c|}
\hline SN & Species & $\begin{array}{c}\text { Seed } \\
\text { density } \\
\left(\mathbf{M}^{-2}\right)\end{array}$ & $\begin{array}{c}\text { Seed Rel. } \\
\text { Density } \\
(\%)\end{array}$ & $\begin{array}{l}\text { Seed Freq } \\
(\%)\end{array}$ & $\begin{array}{c}\text { Seed Rel. Freq } \\
(\%)\end{array}$ & IVI (\%) & Rank \\
\hline 1 & $\begin{array}{c}\text { Cleome } \\
\text { rutidosperma }\end{array}$ & 82 & 7.15 & 33 & 10.0 & 17.12 & 4 \\
\hline 2 & $\begin{array}{c}\text { Dissotis } \\
\text { runtoidifolia }\end{array}$ & 82 & 7.15 & 33 & 10.0 & 17.12 & 4 \\
\hline 3 & $\begin{array}{l}\text { Euphorbia } \\
\text { heterophylla }\end{array}$ & 82 & 7.15 & 33 & 10.0 & 17.12 & 4 \\
\hline 4 & Sorghum halenpense & 164 & 14.30 & 33 & 10.0 & 24.27 & 2 \\
\hline 5 & Kyllinga erecta & 327 & 28.51 & 67 & 20.2 & 48.75 & 1 \\
\hline 6 & Mitracarpus scaber & 82 & 7.15 & 33 & 10.0 & 17.12 & 4 \\
\hline 7 & Phyllantius amarus & 82 & 7.15 & 33 & 10.0 & 17.12 & 4 \\
\hline 8 & Phyllantus riniri & 164 & 14.30 & 33 & 10.0 & 24.27 & 2 \\
\hline \multirow[t]{2}{*}{9} & Poulzozia guineense & 82 & 7.15 & 33 & 10.0 & 17.12 & 4 \\
\hline & Total & 1147 & 100.00 & 331 & 100.0 & 200.00 & \\
\hline
\end{tabular}

Table 7. Species Abundance of Seed banks at Law Faculty Forest at Soil Dept of $11-15 \mathrm{~cm}$

\begin{tabular}{cccccccc}
\hline SN & Species & $\begin{array}{c}\text { Seed density } \\
\left(\mathbf{M}^{-2}\right)\end{array}$ & $\begin{array}{c}\text { Seed Rel. } \\
\text { Density (\%) }\end{array}$ & $\begin{array}{c}\text { Seed Freq } \\
(\mathbf{\%})\end{array}$ & $\begin{array}{c}\text { Seed Rel. } \\
\text { Freq (\%) }\end{array}$ & IVI (\%) & Rank \\
\hline \multirow{2}{*}{1} & $\begin{array}{c}\text { Cleome } \\
\text { rutidosperma }\end{array}$ & 82 & 20.00 & 33 & 25.0 & 45.00 & 2 \\
2 & Kyllinga erecta & 164 & 40.00 & 33 & 25.0 & 65.00 & 1 \\
3 & Mitracarpus scaber & 82 & 20.00 & 33 & 25.0 & 45.00 & 2 \\
4 & Poulzozia guineense & 82 & 20.00 & 33 & 25.0 & 45.00 & 2 \\
& Total & 410 & 100.00 & 132 & 100.0 & 200.00 & \\
\hline
\end{tabular}

Table 5 shows the species abundance of seed banks of law faculty forest site sampled at soil depth of $0-5 \mathrm{~cm}$. The table revealed that Oldenlanda corymbosa recorded the highest important value index of $46.54 \%$ and therefore the most abundance. Oldenlanda corymbosa is followed by Ageratum conyzoides and Kyllinga erecta with important value index of $34.35 \%$ and $31.33 \%$ respectively.

Table 6 reveals the species abundance of seed banks of law faculty forest site sampled at soil depth of $6-10 \mathrm{~cm}$. The table showed that Kyllinga erecta recorded the highest important value index of $48.75 \%$ and therefore the most abundance. Kyllinga erecta is followed by Sorghum halenpense and Phyllantus niruri with important value index of $24.27 \%$ each.

Table 7 shows the species abundance of seed banks of law faculty forest site sampled at soil depth of $11-15 \mathrm{~cm}$. The table showed that out of the four species identified at soil depth, Kyllinga erecta recorded the highest important value index of $65.00 \%$. 
Table 8. Species Diversity of Seed Banks of the Study Site

\begin{tabular}{|c|c|c|c|c|}
\hline Site & Soil Dept & S (Number of Species) & $\begin{array}{c}\mathbf{H}^{\mathrm{I}}=\text { Shannon Wieners } \\
\text { index }\end{array}$ & $\mathbf{E}=$ Equitability \\
\hline \multirow{4}{*}{ Botanical Garden } & $0-5 \mathrm{~cm}$ & 13 & 1.391 & 0.542 \\
\hline & $6-9 \mathrm{~cm}$ & 10 & 1.781 & 0.773 \\
\hline & $11-15 \mathrm{~cm}$ & 2 & 0.693 & 0.919 \\
\hline & $\begin{array}{l}\text { Botanical } \\
\text { Garden }\end{array}$ & 18 & 1.288 & 0.744 \\
\hline \multirow{4}{*}{$\begin{array}{l}\text { Law Faculty Forest } \\
\text { site }\end{array}$} & $0-5 \mathrm{~cm}$ & 12 & 1.551 & 0.624 \\
\hline & $6-9 \mathrm{~cm}$ & 9 & 1.814 & 0.826 \\
\hline & $11-15 \mathrm{~cm}$ & 4 & 1.332 & 0.961 \\
\hline & Law faculty & 15 & 1.566 & 0.803 \\
\hline
\end{tabular}

Table 9. Pearson Momentum Correlation of Abundance and Diversity Measures of the Study Sites

\begin{tabular}{ccccc}
\hline Variables & Number of Species & Shannon Wieners index & Equitability & Soil Dept \\
\hline Number of Species & 1 & & & \\
Shannon Wieners index & .685 & 1 & 1 & \\
Equitability & $-.918^{* *}$ & -.341 & $.972^{* *}$ & 1 \\
Soil Dept & $-.963^{* *}$ & -.500 & \\
\hline
\end{tabular}

**. Correlation is significant at the 0.01 level (2-tailed)

\subsection{Species Diversity of Seed Banks of the Study Site}

Table 8 shows the species diversity of seedbanks of the sites. The species diversity (equitability) values for various depths at the botanical garden were as follows: 0.542 for soil depth of $0-5 \mathrm{~cm}, 0.773$ for soil depth of $6-10$ $\mathrm{cm}$ and 0.919 for soil depth of $11-15 \mathrm{~cm}$. The species diversity (equitability) values for various soil depth were also as follows: 0.624 for soil depth of $0-5 \mathrm{~cm}, 0.826$ for soil depth of 6-10 cm and 0.961 for soil depth of $11-15 \mathrm{~cm}$. Botanical garden site recorded species diversity (equitability) value of 0.744 while law faculty forest site recorded species diversity (equitability) value of 0.803 .

Table 9 shows the Pearson Momentum Correlation of abundance and diversity measures of the study sites. The table revealed that species diversity (equitability) was significantly and positively correlated with soil depth while the number of species was significantly and negatively correlated with soil dept. More so, number of species was significantly and negatively correlated with equitability. This result therefore implies that for the study site, as number of species increases, species diversity decreases and vice versa.

\section{Discussion}

At the botanical garden study site, 13 species were identified at soil depth of $0-5 \mathrm{~cm}, 9$ species were identified at soil depth of $6-10 \mathrm{~cm}$ while 2 species were identified at soil depth of $11-15 \mathrm{~cm}$. For the law faculty forest site, 12 species were identified at soil depth of $0-5 \mathrm{~cm}, 9$ species were identified at $6-10 \mathrm{~cm}$ while 4 species were identified at soil depth of 11-15 cm. Specifically, 18 species were identified in botanical garden while 15 species were identified in law faculty forest sites with some seeds of species like Ageratum conyzoides, Sorghum halenpense, Phyllantus niruri and others found at both sites, this place the total number of species identified in both sites to be 24 . Table 2-7 therefore shows the most representative species of the two study sites to be Eleusine indica, Kyllinga erecta, Ageratum conyzoides, Oldenlandia corymbose, Adiantum sp, Sorghum halenpense and Phyllantus niruri. About half the species identified were found at soil depth of 0-5 cm while slightly above one-third of species identified were found at soil depth of $6-10 \mathrm{~cm}$. less than $20 \%$ of total species identified were found at soil depth of $11-15 \mathrm{~cm}$.

This study corroborates the previous studies, since soil seed banks resemble other biological reservoirs, such as invertebrate eggs, tubercles and bulb banks, spores of non-spermatophyte plants and fungi, or seeds retained on mother plants (serotiny). Soil seed banks are both the outcome of environmental or plant developmental contingencies of evolutionary history [15]. Climate, herbivory and disturbances vary and lead directly to year-to-year changes in soil seed bank density and spatial heterogeneity. Some environments particularly favour the evolution of persistent soil seed banks, such as river mud flats or ephemeral ponds, pastures and arable fields since they are often or intensely disturbed.

The species diversity (equitability) values for various depths at the botanical garden were as follows: 0.542 for soil depth of $0-5 \mathrm{~cm}, 0.773$ for soil depth of $6-10 \mathrm{~cm}$ and 0.919 for soil depth of $11-15 \mathrm{~cm}$. The species diversity (equitability) values for various soil depth were also as follows: 0.624 for soil depth of $0-5 \mathrm{~cm}, 0.826$ for soil depth of 6-10 cm and 0.961 for soil depth of 11-15 cm. Botanical garden site recorded species diversity (equitability) value of 0.744 while law faculty forest site recorded species diversity (equitability) value of 0.803.Moreover, from the study it was observed that seed banks may facilitate the coexistence of potentially competing species and mitigate the effects of inter- and intra-specific competition. This role has also been described as the 'storage effect', a mechanism of 
coexistence that allows many species to persist at the same locality because they have different means of responding to changing environmental conditions and of using resources. In agro ecosystems, the soil seed bank is closely related to weed studies; most of the seeds in the seed bank come from the nearby parent plants, while the remaining seeds are contributed by plant communities a long distance away from the parent plant [16].

In agreement with this study, seed bank plays a critical role in vegetation maintenance, succession, ecosystem restoration, differential species management and conservation of genetic variability $[2,10]$. It is well known that soil seed banks, which are considered to be a potential vegetation community, can facilitate the renewal of vegetation [14,17]. Soil seed bank have been applied widely in vegetation restoration projects. In order to improve vegetation structure and composition, the addition of some missing guilds would facilitate restoration, provided that post-clearing follow-up treatments do not prevent or hinder the establishment of these indigenous species. Interestingly, this study did not verify the findings of some other authors who have suggested that the establishment of new species in severely disturbed areas is more dependent on the seed bank, by contrast, the restoration in less disturbed and mature meadows did not rely on seed banks, and the establishment of the vegetation in these communities is more likely to rely on seed dispersal from the standing vegetation and on species with vegetative reproduction.

\section{Conclusions}

In conclusion, soil seed bank plays an important role in the vegetation restoration process and it is essential that management plans are taken into consideration with the differences in seed bank development of each site. This study suggested that the soil seed bank would be adequate to enable a functional cover of indigenous vegetation to re-establish after clearing. Although, further studies should be carried out on soil seed bank in other types of forest; such as the savanna forest vegetation and the mangrove vegetation, this will help in understanding better the strategic role of soil seed bank in regeneration, restoration and sustenance of vegetations.

\section{REFERENCES}

[1] Bakker JP, Poschlod P, Strykstra R, Bekker R, Thompson K. Seed banks \& seed dispersal. Important topics in restoration ecology. Acta Botanica Neerlandica; 45: 461-490, 1996.

[2] Adams VM, Marsh DM, Knox JS. Importance of the seed bank for population viability and population monitoring in a threatened wetland herb. Biological Conservation; 124: 425-436, 2005.

[3] Ali N, Probert R, Hay F, Davies H, Stuppy W. Post-dispersal embryo growth \& acquisition of desiccation tolerance in Anemone nemorosa (L) seeds. Seed Science Research; 17: 155-163, 2007.

[4] Harrod RJ, Halpern, CB. Effects of experimental burning on individual performance and population structure of two rare plants of north central Washington. Restoration Ecology; 17: 215-225, 2009.

[5] Bossuyt B, Honnay O. Can the seed bank be used for ecological restoration? An overview of seed bank characteristics in European communities. Journal of Vegetation Science; 19: 875-884, 2008.

[6] Jongepierova I, Jongepier JW, Klimes L. Restoring grassland on arable land; and example of a fast spontaneous succession without weed dominated stages. Preslia; 76: 361-369, 2004.

[7] Benvenuti S. Natural weeds seed burial: effect of soil texture, rain and seed characteristics. Seed Science Research; 17: 211-219, 2007.

[8] Bernhardt KG, Koch M, Kropf M, Ulbel M,Webhofer J. Comparison of two methods characterizing the seed bank of amphibious plants in submerged sediments. Aquatic Botany; 88:171-177, 2008.

[9] Holmes PM. Depth distribution and composition of seed-banks in alien-invaded and uninvaded fynbos vegetation. Austral Ecology; 27: 110-120, 2002.

[10] Davis AS, Schutte BJ, Iannuzzi J, Renner KA. Chemical \& physical defence of weed seeds in relation to soil seedbank persistence. Weed Science; 56: 676-684, 2008.

[11] Fisher JL, Loneragan WA, Dixon K, Veneklaas EJ. Soil seed bank compositional change constrains biodiversity in invaded species-rich woodland. Biology of Conservation; 142: 256-269, 2009.

[12] Gioria M, Osborne B. The impact of Gunnera tinctoria(Molina) Mirbel on soil seed bank communities. Journal of Plant Ecology; 2: 153-167, 2009a.

[13] Gioria M, Osborne B. Assessing the impact of plant invasions on soil seed bank communities: use of univariate \& multivariate statistical approaches. Journal of Vegetation Science; 20: 547-556, 2009b.

[14] Gioria M, Osborne B. Similarities in the impact of three large invasive plant species on soil seed bank communities. Biological Invasion; 12: 1671-1683, 2010.

[15] Gaertner M, Breeyen AD, Hui C, Richardson DM. Impacts of alien plant invasions on species richness in Mediterranean-type ecosystems: a meta-analysis. Progress Physical Geography; 33: 319-338, 2009.

[16] Gardarin A, Durr C, Colbach N. Modeling the dynamics \& emergence of a multispecies weed seed bank with species traits. Ecological Modeling; 240: 123-138, 2012.

[17] Meyer SE, Allen PS. Predicting seed dormancy loss and germination timing for Bromus tectorum in a semi-arid environment using hydrothermal time models. Seed Science Research; 19:225-239, 2009. 